\title{
DEPoIMENTO SOBRE A ESTADIA NA UFRGS
}

\author{
Rolando Grillo \\ Pace University - UFRGS
}

Studying abroad at UFRGS for a semester was an experience I am deeply grateful for and one 1 benefited greatly from. Having no experience of studying in South. America and only knowing a fair level of Portuguese, I was little skeptical about how pleasant my experience would be. However, thanks to Prof. Claudia Lima Marques and the rest of the faculty and student board at UFRGS, my stay in Porto Alegre turned out to be a very pleasant and beneficial one.

My endeavor began in early February, when I was welcomed at the airport by cutrent students and alumni from UFRGS. From that very first day, when I was received with open arms, Prof. Claudia and the rest of the faculty at UFRGS showed the utmost respect and willingness to help me and the other exchange students in anything we needed. From the smallest tasks such as registering for classes and helping us adapt to life in Brazil, to helping us get internships, the UFRGS faculty members were most helpful. Their aid continued on throughout my stay in Porto Alegre, and even after I hade rcturned home, when they made sure I had all the necessary paperwork and forms to resume my studies in New York.

As a Finance major, this experience in Porto Alegre helped me attain a betrer understanding of the market and business in South America. During my stay there, I had the privilege to attend EIDAS 2006, an international conference on commerce and future economic development in South America. This experience was one of the highlights of the whole program in Porto Alegre, and has already proved to be very beneficial to the further development of my career.

In conclusion, I'd like to sincerely thank Prof Claudia I.ima Marques and the rest of the UFRGS faculty members for all their help and dedication throughout my stay in Porto Alegre. Without their help, I have no douht my experience would not have been as pleasant as it was.

Thank you. 
